\title{
British-Qualified Accountants Outside the UK: Post-Brexit Case
}

\author{
Ousman Jallow ${ }^{1 *}$, Zaenal Fanani ${ }^{2}$, Hamidah $^{3}$
}

\section{AFFILIATION:}

${ }^{1}$ School of Business and Public Administration, The University of The Gambia, Kanifing, The Gambia $1,2,3$ Faculty of Economics and Business, Airlangga University, Indonesia

*CORRESPONDENCE:

jallowjery1@gmail.com

THIS ARTICLE IS AVAILABLE IN:

https://ojs.unud.ac.id/index.php/jiab

DOI:

10.24843/JIAB.2021.v16.i01.p11

CITATION:

Jallow, O., Fanani, Z., \& Hamidah. (2021). British-Qualified Accountants Outside the UK: PostBrexit Case. Jurnal Ilmiah Akuntansi dan Bisnis, 16(1), 163-172.

\section{ARTICLE HISTORY}

Received:

07 May 2020

Revised:

06 July 2020

Accepted:

13 July 2020

\begin{abstract}
This study aims to explore the impact of Brexit on the employment of accountants and auditors who already had a UK qualification and also assess if they will be allowed to work outside the UK after Brexit. The data collected through interview and collation of previous research articles, reports magazine, and other secondary source of data. Results revealed that auditors and accountants might be potentially affected negatively by a change in their capacity to carry out audits and accounting service across borders, as the number of those who carry out such work may be quite small. As the shape of Brexit becomes more explicit, the Financial Reporting Council's primary objective is to have a seamless transition and a continuation of high professional standards and a properly functioning audit and accountancy profession.
\end{abstract}

Keywords: brexit, accountants, european union, united kingdom

\section{Introduction}

The paper attempts to provide the range of possible outcomes for accountants and auditors after Brexit and further describe the situation of brexit as it exists in UK and outside. An evident from previous studies Lynn et al. (2017); Begg \& Mushövel (2018) was the lack of clarity on the part of many accountants and auditors who may be significantly affected by Brexit as to how best to prepare and secure there employability and qualifications. The lack of clarity about what Brexit will ultimately take expressed reductively in the "Hard Brexit or Soft Brexit" debate. Several stakeholders have chosen to wait it out until clarity emerges. However, for some others, the potential consequences of Brexit have urged them to engage in trying and shaping that debate. In a notice issued on 19 January 2018, the European Commission states that in the absence of a ratified withdrawal agreement, the UK will become the third country on $31^{\text {st }}$ January 2020 to exit the European Union after Algeria and Greenland.

Parts of the Directive of EU regarding employment are implemented in the UK Directive 2000/78/EC, mostly related to employment rights. Brexit will have a potential effect on employment rights. It means by withdrawing from the EU, UK employment rights under EU law would no longer be guaranteed. Some rights derive from the EU Treaty; for example, the right to equal pay would automatically cease to apply upon exit from the EU (Bayer, 2019). 


\section{Jallow, Fanani \& Hamidah \\ British-Qualified Accountants Outside the UK: Post-Brexit Case}

Free movement has worked well for employers. However, many of the employers that took part in the research believe that the leave vote, combined with the Government's stance on both Brexit and immigration, will lead to restrictions. They recognize that the situation is complex and appreciate the administrative difficulties facing the government in terms of EU nationals already in employment and the management of future inflows of EU nationals (Mathews \& Francois, 2018). Elam \& Mendez (2016) it is understandable that low skilled employers are fearful of migration restrictions given their reliance on migrants to fill vacancies. According to the survey data, difficulties filling semi-skilled or unskilled vacancies with local applicants is the most popular reason for recruiting EU nationals. More positively, some employers are aware that if they were to improve their job offer they might attract a wider pool of applicants (Birrell et al., 2016). Indeed, one of the positive outcomes from Brexit and the prospect of migration restrictions is the recognition that employers may have to target under-represented groups in the UK labor market such as older workers, women returners, and ex-offenders to offset the prospect of labor or skills shortages. This is evident in the professional services sector, among others (Oyeranmi, 2014). At the same time, it also seems clear that some employers of the accounting profession are also doubtful about the impact that improving pay and employment conditions, investing in skills, and exploring all recruitment channels would have on stimulating interest among applicants from the domestic workforce. Poor image of their sector, a lack of progression opportunities and record low levels of unemployment in areas such as the south-west of England and the East Midlands, alongside other supply constraints such as the suitability of some applicants for roles in many regions of the UK indicate that employers may need an additional labor shortage safety net. Many employers are also reporting high levels of anxiety among the EU nationals that they currently employ in relation to their future employment status. In addition, employers who report hiring fewer EU nationals since the UK's decision to leave the European Union say that the depreciation in sterling and the current uncertainty about the employment status of EU nationals are the most important factors behind this. Alongside the following policy recommendations, employers tell us that they would like to see a more positive narrative from government about the valuable contributions that EU nationals can and do make, to prevent further loss of valuable workers (Clegg, 2019).

A recent survey has indicated that the accountancy profession is well placed to accommodate the uncertainties surrounding Brexit. A survey carried out of 100 accountancy firms highlighted that $45 \%$ of firms planned on offering more advisory services to assist clients dealing with the impact of the withdrawal of the United Kingdom from the European Union (Bayer, 2019). The survey revealed that many accountants have seen a noticeable increase in the number of clients approaching them for advice surrounding the potential risks resulting from Brexit. Heinz (2016), conducting the survey noted, while there continue to be uncertainties, Brexit offers many opportunities for accountants. Those firms surveyed identified the impact upon the customs, excise, and VAT procedures as being their key concern regarding the UK's withdrawal from Europe. The survey also showed that accountancy firms consider that technology will be the most important aspect to ensure that clients can deal with the impact of Brexit. The financial reporting council FRC (2019a) has also recently commented on the potential detrimental impact leaving the EU may have on the UK's economy. Those accountants involved in the auditing of companies' accounts are also 


\section{Jallow, Fanani \& Hamidah \\ British-Qualified Accountants Outside the UK: Post-Brexit Case}

likely to be keeping a close eye on the impact caused by Brexit upon their client's accounts.

This study is motivated by the lack of previous studies and the limited peer reviewed done earlier. Due to the novelty and complexity of Brexit and the fate of accountants, no previous research was conducted related to this area, all previous research was concentrated on Brexit as a whole. Peer reviewed literature on the topic was also largely concentrated on legal implications, financial and economic implications, and international business and trade

This study intends to fill this gap by taking a closer look at brexit and employability of accountants in deep. However, it is the first time a study is conducted on the faith of employability in the event of hard Brexit that combines both Auditors and Accountants. The result of the study is expected to be useful to practitioners and employers in making a solid and reliable decision on becoming an accountant or not and whether to have a qualification recognized by the UK only and accepted by other European countries. It is also of an added knowledge to the stream of the already existing literature in the study of Brexit and the state of accountants form earlier studies of (Heinz, 2016; Birrell et al., 2016). The main contributions of this study to the literature are as follows. First, the study hopes to assist standards regulatory bodies in setting standards and related auditing programs for required necessary qualifications for professional accountants outside the UK through standardized curriculum. Secondly, the results from the study has the potential to open up new areas of research that may interest students and future researchers. This can be achieved through a clear understanding of the concept, principles, objectives, and approach of auditing and accounting curriculums. Also, the study aims to assist normative regulators in determining the appropriate improvement program and accreditation requirements that external auditors must have before they can conduct legitimate audits on a UK-EU basis. Furthermore, the research hopes to recommend and suggest some solutions for the obstacles and challenges that face accountants and auditors outside the UK.

The rest of the paper is structured as follows; a detailed research methodology followed by results and discussions which discussed the main findings from interviews and academic literature in other to justify the findings of the study. The final section consists of the conclusion and limitations of the study.

The study aims to explore the impact of Brexit on employment of accountants and auditors who already had a UK qualification. Specifically, the paper scrutinized previous literatures where intentions of auditors and accountants to make changes to their career plans as a predictor of the future behaviors of auditors and accountants in the UK.

The study makes use of the diffusion of innovation (DOI) theory to give a detail explanation of the level of adoption of Brexit. The diffusion of innovation theory model was first brought to the world stage by Rogers in the year 1962, with the main concept evolving over later editions (Rogers, 1983). The diffusion of innovative theory posit that innovation diffusion is a general process not tied by the type of invention and innovation, by who the adopters are or by place or culture. Rogers (1983) defined diffusion as the process by which an innovation is communicated via various channels over time and among the members of a particular social system.

As explained above, Rogers (1983) argued that agents of change are needed for an innovation to be adopted, that uncertainty reduces the speed of innovation 


\section{Jallow, Fanani \& Hamidah \\ British-Qualified Accountants Outside the UK: Post-Brexit Case}

adoption, and that the adopters of innovation should be aware of its benefits and dangers. Rogers (1983) further suggested that diffusion of innovation theory entails certain attributes, such as relative advantage, perceived complexity, and perceived compatibility which are vital for the adoption of an innovation. For companies in Indonesia to understand and share information regarding Islamic banking products such as Sukuk, conferences and seminars need to be organized by interested bodies, such as the Bank Indonesia (BI), religious and political leaders and the marketing departments of Islamic banks and public relations offices (Bananuka et al., 2020). The citizenry need to be aware of the gains and losses of adopting and Brexit or not.

\section{Research Method}

This study used a descriptive type of research. The purpose of employing this method is to describe the nature of the situation, as it exists at the time of the study, and to explore the cause/s of particular phenomena (Boswell \& Cannon, 2014). This research is based on the qualitative research method. It allowed an investigation of important new issues and questions as they arose (Merriam, 2002). This study also used this method of research since this research intends to find results that would explain the relationship of one variable with another variable through qualitative elements in research. These qualitative elements are behavior, attitudes, opinions, and beliefs. The study used this kind of research considering the goal of the study to obtain sound and reliable information to formulate rational conclusions and recommendations for the study (Creswell, 2009). The study chose this method to help determine the meaning behind the human experiment because it is connected to a way of thinking about the study of social reality Strauss \& Corbin (1998).

Data was gathered through a face to face personal interview with a practitioner in the field of academic and accounting by the name D. Gillatt, the Director of Business Frameworks. The secondary data which involve articles based on brexit and its impact on accountants was also gathered through a collection of published articles from reputable journals using keywords such as; Brexit, UK auditor, and UK employment that relates to the topic of interest. Secondary data collection data was mostly used considering the unavailability of data and cost-effectiveness.

Data collection for this paper occurred through interview designed to explore the lived experiences of UK accountants who had interacted in the Brexit. The participant is asked to attend a scheduled interview of approximately 45-60 minutes. Interviews are particularly effective for gathering data about participants' living experience (Creswell, 2009). Interviews were conducted with a semi-structured approach reflecting the framework presented in the literature in English language. Although the questions are from Frequently Ask Questions (FAQ) from UK-Accountants posted in the Financial Reporting Council (FRC) website with prompts to guide the interview questions. Interview times and dates were determined through direct contact with Director, Business Frameworks in charge before one month to best establish availability and convenience for the purpose of this study, FRC refers to Financial Reporting Council that provides auditing and ethical standard guidance for UK accountants. The interview was conducted on the $15^{\text {th }}$ of January 2020. 


\section{Result and Discussion}

Since the economic recession of 2008 and the crisis in Greece, the UK people had questioned the benefits of remaining in the EU, particularly when the UK economy remained relatively steady. Growing EU immigration into the UK and increasing EU regulation were also contributory factors to the growing anti-EU sentiment (IFAC, 2010). UK listed companies were first required to report under International Financial Reporting Standards ('IFRS') in 2005. This was mandated by the European Union, to harmonize accounting across Europe but in a manner that also sought to achieve comparability with reporting in the rest of the world. In this the EU was largely successful: the IFRS Foundation reports that 144 countries now require the use of IFRS for all or most listed companies, with another 12 countries permitting its use (IFAC, 2013). Global financial reporting has ceased to be characterized by numerous disparate national systems; to the point that today there are now essentially only two: IFRS and US Generally Accepted Accounting Principles (US GAAP). Several benefits are arising from common accounting standards. The use of a single, familiar accounting framework enhances both the comparability and credibility of financial information across the globe. This leads to more efficient and better-informed decisions and has helped spur the development of global capital markets, reducing the costs of capital.

The UK's departure from the EU may impact on whether the training and qualifications obtained by members based in the UK would be viewed as sufficient for the purposes of the legislation, and accordingly whether the members of UK bodies can be recognized as auditors (McGrath \& Gourley M. 2018). While this may not be an issue at the date of Brexit, members who train post-Brexit may not meet these requirements. It is also possible that the UK would decide to keep their training and qualifications processes in compliance with EU law to demonstrate equivalence between qualifications and allow for reciprocity agreements between EU member states and the UK. At a minimum, this might allow a UK member who moved to the EU to show that they held the same audit qualification as a member of an EU member state (Kapoor, 2019). The issue of the recognition of professional qualifications is a wider Brexit issue that applies across many professions.

The analysis is made by answering some frequently asked questions that are posed by the UK accountants, this helped in analyzing the data from the gathered material, and based on the conducted interview.

Interviewer: I have already had my qualification recognized in the UK. Will this recognition still stand on $1^{\text {st }}$ February 2020?

"Existing registrations of individual European Economic Area EEA auditors as UK statutory auditors will continue after the UK's exit from the EU. The UK is also providing unilateral transitional arrangements for EEA qualified auditors to become UK statutory auditors by beginning an aptitude test process before 31 December 2020. From 1 January 2021 new arrangements will be put in place that reflect that EEA states will be third countries to the UK (EC, 2019). However, we hope that mutual recognition agreements will be put in place that will facilitate the process of recognition of qualifications between the UK and EEA states"

Interviewer: UK auditors are currently in my EEA firm's ownership and management structure. What happens now? 


\section{Jallow, Fanani \& Hamidah \\ British-Qualified Accountants Outside the UK: Post-Brexit Case}

"You need to check with your firm to understand what, if any, restructuring arrangements have been put in place to ensure it continues to comply with the requirements in the Audit Directive (that EEA auditors are a majority of members of the management board and hold a majority of voting rights). Firms registered in an EEA State should consider whether that registration will be affected if the voting rights of UK auditors are no longer counted as part of the required majority of owners and managers of the firm. This is because UK statutory auditors will no longer count towards these required majorities after exit day."

Interviewer: Will I have to register to be able to work in the Republic of Ireland?

"Yes. Despite the Common Travel Area agreement, UK auditors including those with a residential address in Northern Ireland will need to register with the Irish Auditing \& Accounting Supervisory Authority (IAASA) and pass an aptitude test in Irish tax and law."

Interviewer: I qualified in the Republic of Ireland. Do I still need to do an aptitude test to continue working in the UK?

"Not if your qualification has been awarded by a professional body that is recognized in both the UK and Ireland. Most audit qualifications in the UK and the Republic of Ireland are recognized in the UK. For other auditors, the aptitude test will continue to be made available."

Interviewer: Will EEA auditors continue to be counted in a UK firms' majority for ownership and control purposes?

"Yes. Individual EEA auditors will continue to count towards those eligible to control UK audit firms after EU Exit. The UK is granting this to EEA auditors on a unilateral basis. However, there will be no provision for EEA audit firms to be eligible to control UK audit firms after $1^{\text {st }}$ February 2020."

Interviewer: If it is likely that I will no longer be recognized as a statutory auditor in the EEA after $1^{\text {st }}$ February 2020 what should I do?

"You will need to decide whether to seek recognition as a statutory auditor in the country that you intend to practice in from $1^{\text {st }}$ February 2020. Depending on the extent to which your UK qualification is recognized in the relevant EEA State, you may need to sit an aptitude test or complete an adaption period, or you may be required to re-qualify by sitting some or all of the examinations and meeting any other requirements needed to obtain an audit qualification in that EEA State. If this is not a practical course of action, then you may need to cease signing audit reports of entities incorporated in that EEA State and to advise your clients accordingly. If you have not already enquired about audit registration in the EEA State(s) you practice in, FRC (2019) recommends you do so without delay."

Interviewer: Will there be any change to the non-audit services that my firm and the other members of its network may provide to the subsidiaries and parents of a UK PIE?"

"Non-audit services on the "blacklist" under Article 5 of the EU Audit Regulation will now be prohibited for all overseas subsidiaries of UK PIEs. This means that, for firms in the same network as a UK auditor of a UK PIE that previously provided blacklisted services to non-EEA subsidiaries, those non-EEA services will be subject to the same prohibition. Meanwhile, EEA auditors and EEA parent undertakings of UK PIEs will not be included under these prohibitions as they were previously. Only UK parent undertakings will be included. These changes will take effect for financial years beginning on or after the exit day." 


\section{Jallow, Fanani \& Hamidah \\ British-Qualified Accountants Outside the UK: Post-Brexit Case}

Many auditors may be potentially affected by a change in their capacity to carry out audits across the border, the number who carry out such work may be quite small. Using available statistics and extrapolating, there may be approximately 200 firms in one jurisdiction who have clients in the other. This is in the context of over 5,000 firms that are approved to audit in Ireland and the UK (Heinz, 2016). Furthermore, some of these firms are parts of networks that will have firms in both jurisdictions, and indeed some individual firms have offices in both jurisdictions so that re-organization of their work will allow them to retain their clients. Equally, it should be considered that although the number of firms is relatively small, behind these there may be a large number of clients who could be affected. There may also be potential issues concerning the legal ownership of some of the larger firms. Some firms are structured as all Islands, GB\&I, and even European firms. They may now need to restructure so that the firm meets the EU ownership requirements. Begg \& Mushövel (2018) the impact of this depends on exactly how it is currently structured, but as many firms will have a large number of UK partners, and the EU law requires that a majority of partners in a firm must be EU auditors for the firm to be an EU audit firm, this could present a significant challenge for these structures. For international firms, the ability to provide services in Europe is a key issue exiting the European union auditor - The Statutory Auditors and Third Country Auditors (Amendment) (EU Exit) Regulations, (2018). Other key impacts for audit firms appear to relate to the portability of the audit qualification and the transfer of people for particular skills and experience across borders, so for example, the ability to transfer audit staff from Ireland to the UK and vice versa on secondment as well as transferring from the UK to other EU countries and vice versa (IAASA, 2018).

If reciprocal rights are not in place, then members of the profession who until now could freely practice throughout these islands, and across the island of Ireland in particular, may now find that considerably more difficult. If it transpires that notwithstanding the mutual recognition across the islands that currently prevails, a hard border for the provision of these services becomes a reality, then those auditors who operate across the jurisdictions would have to adjust. Their options could potentially include registration as a member with bodies recognized in each jurisdiction, so dual membership with the increased costs and regulatory oversight that this will bring, moving registration wholly to the body where they carry out most of their business, and ceasing operations in the other jurisdiction and splitting of firms across jurisdictions.

The EU may more tightly define what is meant by a Member State auditor during Brexit negotiations. Such definition could be by reference either to the location of the Report Acceptance Body RAB, which would mean that for example ICAEW members resident in Ireland as well as the UK would now be third-country auditors or by location of the auditor, which would mean that ICAI members resident in the UK would be third-country auditors. EU take of this matter may arise in the context that ongoing recognition could potentially enable a firm based in London to audit in France or Germany as an EU auditor based on an Irish recognition (FRC, 2019).

As noted earlier, the issue here is the timing of such recognition. Critical for a smooth transfer post-Brexit would be that the preparatory work for such recognition, which is at EU level, would be done in advance of the date of Brexit so that immediately thereafter the equivalence process could be finalized (Clegg, 2019). Future research can focus more on the implication of Brexit on UK accounting regulatory body and standard 


\section{Jallow, Fanani \& Hamidah \\ British-Qualified Accountants Outside the UK: Post-Brexit Case}

setters, future research should also expand the scope of the study to have a more concrete and reliable finding.

\section{Conclusion}

This study attempts to explore the impact of the Brexit on employment of Accountants and Auditors who already had a UK qualification. The study also assess if they will be allowed to work outside the UK after Brexit? The paper has been developed to provide an overview of the various challenges and opportunities that Brexit may bring to the United Kingdom and those entities within its remit concerning Auditors. The study concluded that may auditors may be potentially affected by a change in their capacity to carry out audits across the border, the number who carry out such work may be quite small scale and many auditors have to register in any country outside the UK when there is a no-deal post Brexit to render audit and accounting services.

The purpose of the paper is to stimulate discussion and debate concerning those challenges and opportunities, to provide input and context for stakeholders' strategic and operational planning over the medium term, and to input into the work of Government in its discussions with relevant stakeholders. The study also has the potential to open up new areas of research that may interest students and future researchers.

The study has limited evidence or reference base. Also, the study was conducted on a limited sample, which encompassed a highly experienced and season accountant in the field of accounting. Finally, the collection of data, through interviews, was done by the authors solely. As a result, the study might have a certain degree of subjectivity. In order to mitigate the objectivity, the paper uses a triangulation approached in the interview process.

\section{References}

Bananuka, J., Katamba, D., Nalukenge, I., Kabuye, F., \& Sendawula, K. (2020). Adoption of Islamic banking in a non-Islamic country: evidence from Uganda. Journal of Islamic Accounting and Business Research, 11(5), 9891007. https://doi.org/10.1108/JIABR-08-2017-0119

Bayer, L. (2019). EU auditors raise concerns about Euronews funding. Poltico. https://www.politico.eu/article/eu-auditors-raise-concerns-abouteuronews-funding/

Begg, I., \& Mushövel, F. (2018). The economic impact of Brexit : jobs, growth and the public finances Key messages. European Institute, London School of Economics, 1-5. http://www.niesr.ac.uk/publications/eu-referendum-andfiscal-impact-low-income-households\#.V1qr-4-cHIV 8

Birrell, I., Gerard, S., \& Arthur, R. (2016). The impact of Brexit on UK employment law rights and health and safety legislation - Trade Union Law Group Briefing (Issue September). www.thompsonstradeunionlaw.co.uk

Boswell, C., \& Cannon, S. (2014). critique process in research. Jones and Bartlett publishers. 


\author{
Jallow, Fanani \& Hamidah \\ British-Qualified Accountants Outside the UK: Post-Brexit Case
}

Clegg, R. (2019). UK labour market : Estimates of Employment, Unemployment, Economic Inactivity and other Employment- Related Statistics for the UK. (Issue January).

Creswell, J. W. (2009). Research Design: Qualitative, Quantitative, and MixedMethod: Choosing Among Five Approaches (T. Oaks (ed.); 3rd ed.). Sage Publications.

EC. (2019). Brexit preparedness: EU completes preparations for possible "nodeal" scenario on 12 April. http://europa.eu/rapid/press-release_IP-191813_en.htm

Elam, D., \& Mendez, F. (2016). Career Expectations Of Accounting Students. American Journal of Business Education (AJBE), 3(5), 71-80. https://doi.org/10.19030/ajbe.v3i5.430

FRC. (2019a). FRC-post-brexit-on-audit-and-accounting UK FRC communication on possible no-deal Brexit (p. 6). Financial Reporting Council.

FRC. (2019b). Important Information for Auditors and Firms in Preparation for a Potential No-Deal Scenario. Financial Reporting Council - Department for Business, Energy and Industrial Strategy, 44(0), 1-11. www.beis.gov.uk https://www.pwc.lu/en/press-articles/2016/brexit-impact-on-audit-reform.html IAASA. (2018). Brexit and its potential impact on Audit and Accountancy (Issue May).

IFAC. (2010). 2010 EDITION Scope of the Handbook How the Handbook is Arranged. In International Education (Issue August).

IFAC. (2013). International Ethics Standards Board for Accountants ${ }^{\text {TM }}$ Handbook of the Code of Ethics for Professional Accountants 2013 Edition.

James, J. (2018). Exiting the European Union Auditors- The Statutory Auditors and Third Country Auditors ( Amendment ) ( EU Exit ) Regulations (UK201811051003 11/2018 19585; Vol. 2, Issue 2). http://www.legislation.gov.uk/id/ukdsi/2018/9780111174333.

Kapoor, M. (2019). U.K. Auditors, Regulators Warn of Brexit Risk. Bloomberg Tax. https://news.bloombergtax.com/financial-accounting/u-k-auditorsregulators-warn-of-brexit-risk

Lynn, T., Rosati, P., Quinn, M., \& Murphy, B. (2017). Brexit: The Role of Accounting Firms in the Brexit Discourse on Twitter. September, 1-31.

Mathews, A., \& Francois, J. (2018). Ireland \& the Impacts of Brexit Strantegic Implications for Ireland Arising from Changing EU-UK Trading Relation.

McGrath, E., \& Gourley M., L. (2018). The impact of BREXIT on the application of IFRS in the UK. Ernst and Young EY Policy Pulse Compendium, June.

Merriam. (2002). Assessing and evaluating qualitative research. Qualitative research in practice: Examples for discussion and analysis.

Oyeranmi, S. (2014). European Union and African Union : A Study of Regionalism for Global Integration and Development. Journal for the Advancement of Developing Economies, 3(1), 1-19. https://doi.org/10.13014/K2251GCH 
Jallow, Fanani \& Hamidah

British-Qualified Accountants Outside the UK: Post-Brexit Case

Rogers, E. M. (1983). (Eds.), An Integrated Approach to Communication Theory and Research, Third Edition. The Free Press Macmillan Publishing.

Strauss, \& Corbin. (1998). Basics of qualitative research techniques. Sage Publishers. 